\title{
Boron Steel: An Alternative for Costlier Nickel and Molybdenum Alloyed Steel for Transmission Gears
}

\author{
A. Verma*a, K. Gopinath ${ }^{\mathrm{a}}$ and S.B. Sarkarb \\ ${ }^{*} a$ MDS, Mechanical Engineering Department, Indian Institute of Technology, Madras, India (T.N.) 600036 \\ ${ }^{b}$ Mahindra Ugine Steel Company Ltd., Jagdish Nagar, Khopoli (M.H.) India 410216
}

Received 17 May 2009; accepted 4 October 2009

$$
\begin{aligned}
& \text { صلب البورون: بديل عن سبيكة صلب النيكل والموليبدينوم المكلفة والمستخدمة بالتروس الناقلة } \\
& \text { أند فرما • ، ك. كوبناث و س. ب. ساركار } \\
& \text { الخلاصة: سبائك الصلب المنخفضة مكربنة الغلاف والتي تحتوي على النيكل والكروم والمليبدينوم تستخدم على نطاق واسع بالتروس الناقلة في السيارات } \\
& \text { وذلك لامتلاكها المى الخواص الميكانيكية المرغوبة. من اجل خفض التكاليفة التهايف وتوفير المو اد النادرة مثل النيكل والموليبدينوم في الاستخدامات الاستراتيجية }
\end{aligned}
$$

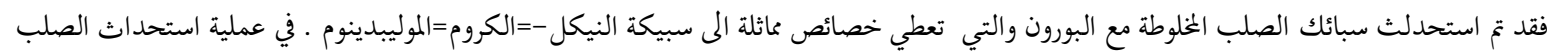

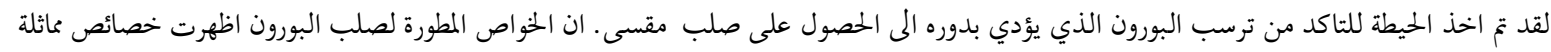

$$
\begin{aligned}
& \text { الى سبيكة صلب النيكل-==الكروم=الموليبدينوم وكانت متفوقة على خواص صلب البوري البورون التبون التقليدية. } \\
& \text { المفردات المفتاحية: صلب التروس، صلب البورون، التشوه المكربن، مقاومة الصدم، التكلفة }
\end{aligned}
$$

\begin{abstract}
Case Carburized (CC) low carbon steels containing Ni, $\mathrm{Cr}$ and Mo alloying elements are widely used for transmission gears in automobile, as it possesses desired mechanical properties. In order to cut cost and save scarce materials like Ni and Mo for strategic applications, steel alloyed with Boron has been developed, which gives properties comparable to Ni-Cr-Mo alloyed steel. In the process of steel development, care was taken to ensure precipitation of boron which results in precipitation hardening. The characterization of the developed boron steel had exhibited properties comparable to Ni-Cr-Mo alloyed steel and superior to conventional boron steel.
\end{abstract}

Keywords: Gear steel, Boron steel, Carburization distortion, Impact strength, Cost

\section{Introduction}

$\mathrm{Ni}-\mathrm{Cr}-\mathrm{Mo}$ alloyed $\mathrm{CC}$ steels are widely used for transmission gears, as it provides combination of soft ductile core, high fatigue strength and surface hardness, thereby wear resistance of contacting surfaces (Wilks, et al. 1994). Overly fluctuating $\mathrm{Ni}$ and Mo cost in the recent times, alarmed automotive industries worldwide, as it affect the final component cost. Vehicle cost plays significant role, when automotive manufacturers compete locally and globally. Hence, automotive industries demand cost effective steels without compromise in mechanical properties, machinability, performance and durability.

Melloy et al. (1973) found optimum combination of

$\overline{\text { *Corresponding author's e-mail: cengg@yahoo.com }}$ hardenability and toughness by adding 15 to $25 \mathrm{ppm}$ of boron. Irvine and Pickering (1957) showed that, $20 \mathrm{ppm}$ of boron results in similar tensile strength, achieved by alloying 1.0\% Cr and 0.7\% Mn. Stumpf and Banks (2006) found 10 to $30 \mathrm{ppm}$ of boron enhances hardenability of steel through segregation at austenite grain boundaries and hence delays the nucleation of ferrite and pearlite. Boron addition did not affect the hot and cold working properties of as rolled steels. It behaves as plain carbon steel but with higher hardenablity, reports Szuch and Delve (1967). Gear tooth bending strength and loading capacity were ensured by impact strength of steel. Lower impact strength results in gear tooth failure. Impact strength of conventional low carbon boron steel (CBS) 
Table 1. Chemical compositions of CBS DBS and Ni-Cr-Mo alloyed steel

\begin{tabular}{|c|c|c|c|c|c|c|c|c|c|}
\hline Elements & $\mathbf{C}$ & $\mathbf{S i}$ & $\mathbf{M n}$ & $\mathbf{C r}$ & $\mathbf{N i}$ & $\mathbf{M o}$ & $\mathbf{B}$ & $\mathbf{A l}$ & $\mathbf{T i}$ \\
\hline Ni-Cr-Mo steel & 0.17 & 0.35 & 0.80 & 0.98 & 1.6 & 0.17 & Nil & 0.020 & Trace \\
\hline $\begin{array}{c}\text { Conventional } \\
\text { Boron steel }\end{array}$ & 0.17 & 0.24 & 1.20 & 1.23 & 0.11 & 0.07 & 0.0019 & 0.020 & 0.020 \\
\hline $\begin{array}{c}\text { Developed } \\
\text { Boron steel }\end{array}$ & 0.18 & 0.22 & 1.24 & 1.21 & 0.14 & 0.04 & 0.0017 & 0.020 & 0.0019 \\
\hline
\end{tabular}

Table 2. Inclusion ratings of the developed boron steel as per ASTM E 45 standard

\begin{tabular}{|c|c|c|c|c|}
\hline $\begin{array}{l}\text { Thickness } \\
\text { classifications }\end{array}$ & A (Sulphides) & B (Aluminate) & C (Silicates) & D (Oxides) \\
\hline Thin & 2.5 & 1.5 & 0 & 1.5 \\
\hline Heavy & 1.0 & 0.5 & 0 & 0.5 \\
\hline
\end{tabular}

(20MnCr5B steel) was inferior to Ni-Cr-Mo alloyed steel (EN353 of BS970 standard). In CBS, titanium (Ti) was added to control the nitrogen because of its higher chemical affinity towards nitrogen than boron. Kapadia et al. (1968) reported that, Ti forms TiN and boron goes free in the solid solution, resulting in higher hardenability of steel. However, in absence of Ti, boron forms precipitates of BN. Hence, reduces effective boron, which was responsible for increasing hardenability of steel. Boron hardenability potential was inversely proportional to the carbon content of the steel (Rahrer and Armstrong, 1947; Irvine and Pickering, 1963). Rahrer and Armstrong concluded that, $\mathrm{Al}$ deoxidized steel forms AlN with nitrogen, which was thermodynamically more stable than BN. But AlN forms more slowly than $\mathrm{BN}$, in austenite.

Considering the above facts, development of low carbon boron steel (DBS) and its merits over CBS and Ni-CrMo alloyed steel for potential gear applications were reported in this paper. The scope restricts to comparison of impact strength, tensile strength and case carburization distortion.

\section{Boron Steel Development}

The process followed to develop low carbon boron steel was EAF - LF - VD - CCP (EAF-Electric arc furnace, LFLadle furnace, VD-Vacuum degassing and CCPContinuous casting process). The same process was followed for development of CBS and Ni-Cr-Mo alloyed steel. The required charge was carefully prepared to control tramp elements such as $\mathrm{Cu}, \mathrm{Sn}$ and $\mathrm{P}$ etc. EAF with EBT (Eccentric bottom tilting) facility was used for steel melting, as it had superior slag control. The slag was tapped in a preheated ladle where molten steel was deoxidized with deoxidizers and fresh lime was added for making fresh slag. The melt was later transferred to the LF station for addition of ferroalloys in order to achieve the desired chemistry and temperature. A reducing slag was created as it aids in melt refining. The ladle was subsequently transferred to the VD station where melt degassing was carried out below $10^{-3}$ bar. VD with continuous argon purging through porous plug ensured removal of gases like hydrogen, oxygen and nitrogen. Boron in the melt was added after VD. Prior to boron addition, the melt was adequately deoxidized with $\mathrm{Al}$ and other deoxidizers.

The melt inclusions were controlled by proper deoxidation, slag physio-chemical characteristics, vacuum degassing, soft rinsing, argon shrouding and tundish metallurgy. The molten steel was cast in a 250 X $200 \mathrm{~mm}$ cast iron mould by continuous casting process (CCP) setup. The CCP setup had mould EMS (Electro magnetic stirrer), auto mould level control (AMLC) device, well designed tundish and sub entry nozzle (SEN) system. The rectangular billets were rolled to achieve reduction ratio of 1:6 or higher on the steel. The typical chemical composition of the Ni-Cr-Mo alloyed steel, conventional low carbon boron steel (CBS) and developed low carbon boron steel (DBS) were shown in Table 1. The compositions of three steels were measured by Spectromax, CCD spectrometer from Spectro AI Gmbh.

\section{Results}

\subsection{Metallurgical Studies}

The test specimen for metallurgical studies were prepared from the forged and annealed (8800C for an hour) steel bars. Grain sizes of steel were measured by comparison chart method as mentioned in the ASTM E112 standard. Mixed grain sizes at 500X were observed for CBS in the Leica make metallurgical microscope. Grain sizes of 5 and finer (9 to 10) were observed for DBS under similar microscope at 500X. The grain size distribution for three steels was shown in Fig. 1. Grains of similar size and uniform distribution were observed for DBS where as CBS showed grains of mixed size and non-uniform distribution. The etching solution was prepared by mixing $100 \mathrm{ml}$ of distilled water with four grams of picric acid and $0.5 \%$ of soap solution. The etching was performed at room temperature for over thirty minutes. The cleanliness study of DBS steel was conducted as per ASTM E 45 standard. The microscopic analyses of inclusion ratings were summarized in Table 2. Microstructure of boron steel shows lamellar pearlite and ferrite only. 

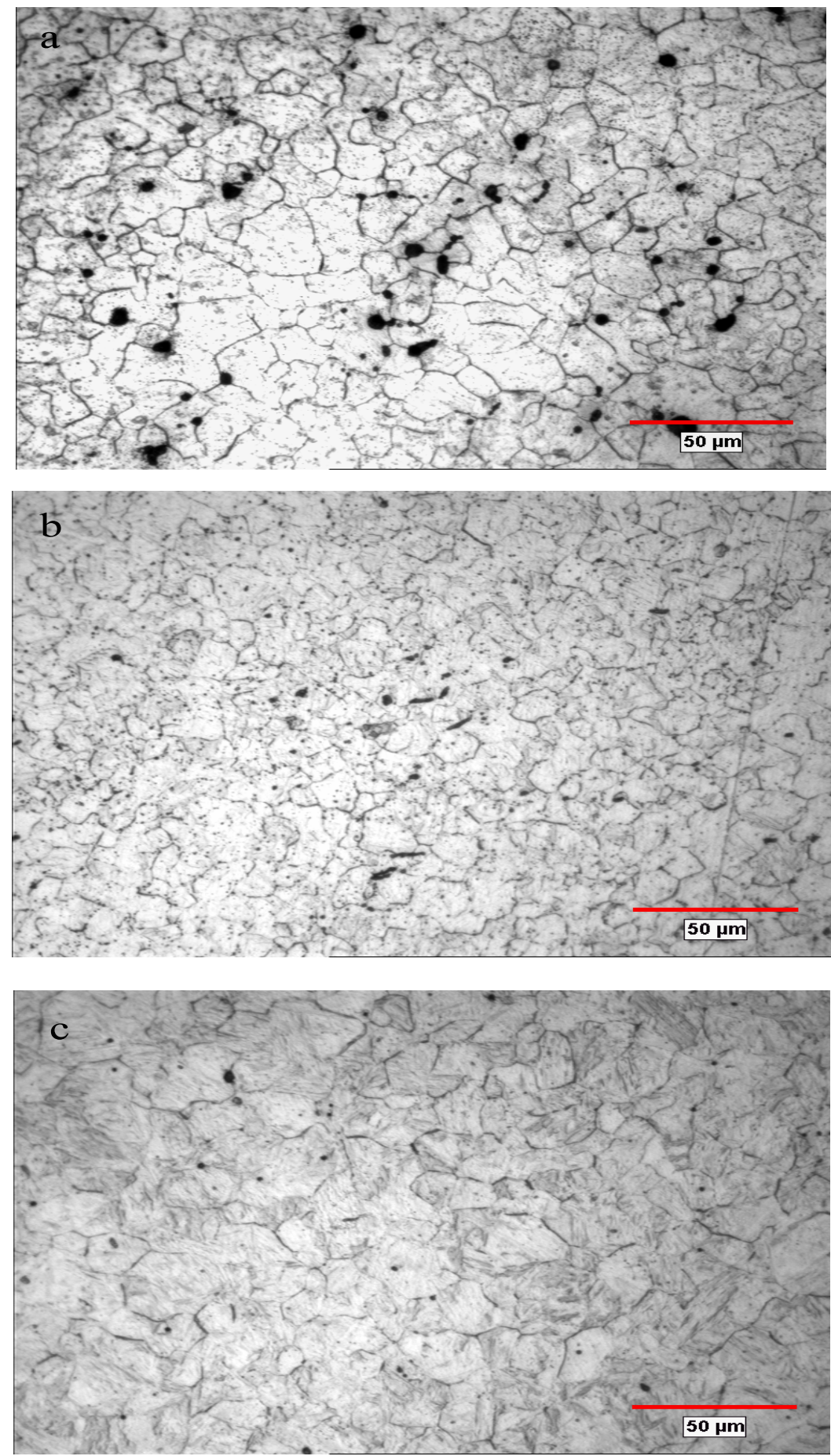

Figure 1. Microscopic image of grain size distrubution in boron steel at $500 \mathrm{X}$ a) Conventional boron steel (CBS), b) Developed boron steel (DBS), c) Ni-Cr-Mo alloyed steel

\subsection{Mechanical Properties Evaluation}

Impact strength qualification of any steel is desired for consideration as gear steel. Instrumented dynamic impact tests were carried out by Brugger test method (Tikhonov and Palagin, 1994). Brugger test specimens (Fig. 2) were prepared from the forged bar of CBS, DBS and Ni-Cr-Mo alloyed steel. The specimens were treated under identical carburizing, hardening, tempering parameters and cycle durations as used for existing Ni-Cr-Mo alloyed steel gears. Specimens from all three steels were carburized in the same batch, so any differences in mechanical properties due to heat treatment parameters and cycles were eliminated. Impact tests were carried out on Zwick / Roell $\mathrm{GmbH}$ make, instrumented dynamic impact testing machine (model RKP 450) at room temperature. Comparison of impact load results of CBS, DBS and NiCr-Mo alloyed steels were shown in Fig. 3. Impact load 

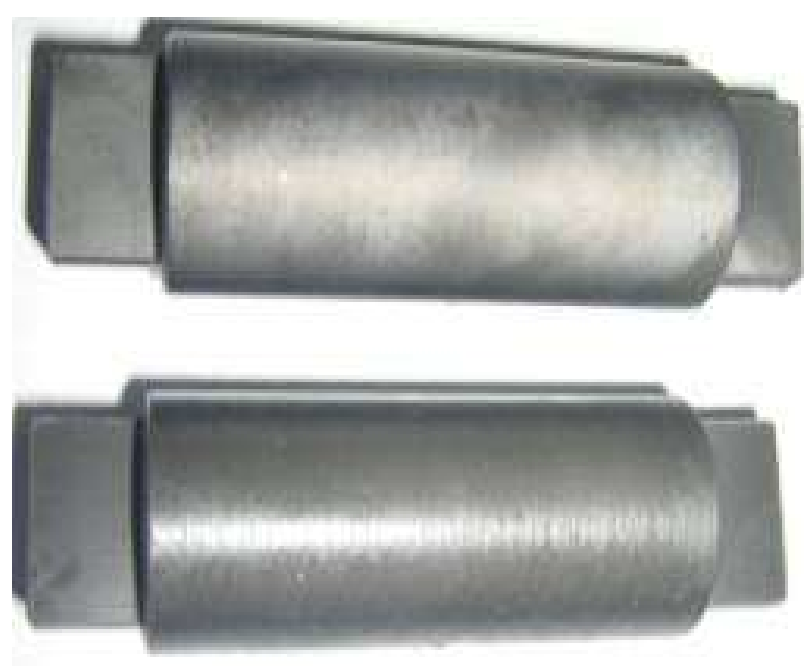

Figure 2. Brugger impact test specimen

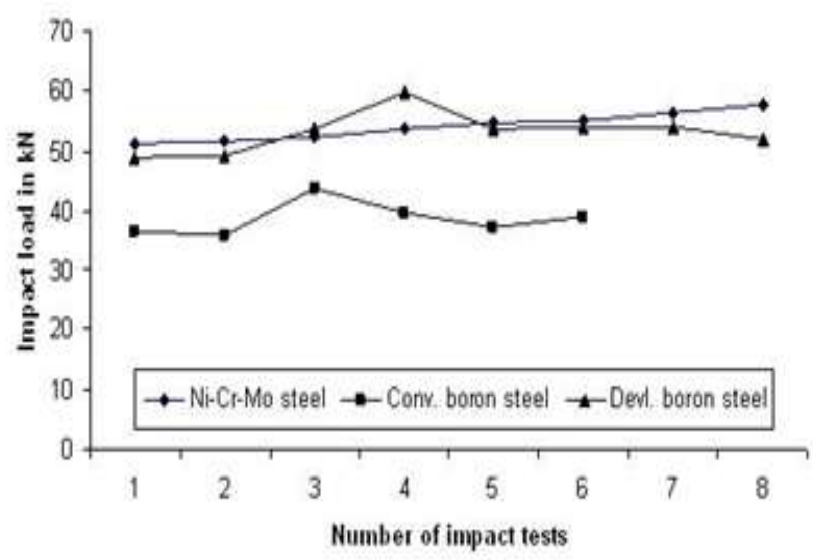

Figure 3. Impact test results of Ni-Cr-Mo alloyed steel and boron steels by Brugger method

for DBS and Ni-Cr-Mo alloyed steel were comparable (52 $\mathrm{kN})$ where as CBS showed lower impact load $(40 \mathrm{kN})$. Mechanical properties of steels (soft condition) were measured on Zwick / Roell GmbH make tensile testing machine (model Z250) and tentative steel costs were compared and tabulated in Table 3. Load Vs deflection curve obtained during tensile testing for all the steels were shown in Fig. 4. DBS showed highest tensile strength of $789 \mathrm{MPa}$ where as CBS showed maximum elongation of $11.73 \%$. Tensile strength and elongation of Ni-Cr-Mo alloyed steel were in between the two boron steels.

\subsection{Comparison of Carburizing Distortion}

Gears from DBS and CBS were forged and machined to similar design and geometrical parameters (weight 5.6 $\mathrm{kg}$, outer diameter (OD) $180 \mathrm{~mm}$ and inner diameter (ID) conforms to 76G5 mm of ISO 286-1: 1988) as used for existing Ni-Cr-Mo alloyed steel gears. In order to avoid geometrical / profile variation due to carburizing and tempering cycles, gears from three steels, were loaded to same batch in a furnace. Twenty five gears from each of the three steels were checked for gear dimensions (ID and ID width) before and after carburization to evaluate distortion / growth pattern. Mitutoyo, Japan make gauges were used for measurement of gear dimensions. The carburizing cycle of duration eight hours, comprises of heating gears to temperature of $930^{\circ} \mathrm{C}$ for carburization and hardened at $830^{\circ} \mathrm{C}$, followed by oil quenching at $110{ }^{\circ} \mathrm{C}$ for twenty minutes. The gears were then tempered at $150^{\circ} \mathrm{C}$ for more than three hours. All the gears were metallurgically characterized and results were reported in Table 4.

The grinding / finishing stocks on gear ID post carburizing were plotted in Fig. 5. ID distortion signifies the deviation of circularity measured at three locations over gear ID width and average result reported. ID distortion trend of DBS gears, were comparable (average $0.225 \mathrm{~mm}$ ) to that of existing Ni-Cr-Mo alloyed steel. The average distortion of CBS gears were $0.400 \mathrm{~mm}$, higher compared to DBS and Ni-Cr-Mo alloyed steel by about $0.175 \mathrm{~mm}$. Gears ID width (measured along the gear axis) distortion trend for all three steels were plotted in Fig. 6. DBS gears width growth trend were comparable to $\mathrm{Ni}-\mathrm{Cr}$-Mo alloyed steel with average growth of $0.05 \mathrm{~mm}$. CBS gears width grows by average of $0.09 \mathrm{~mm}$, higher by $0.04 \mathrm{~mm}$ than DBS and existing Ni-Cr-Mo alloyed steel. Gears ID grinding stock trend of all three steels were more consistent than gears width distortion trend. All other gear dimensions (like lead, profile, crowning and span length) of DBS were comparable to Ni-Cr-Mo alloyed steel and with in the specifications ( $\mathrm{K}$ templates) when tested on Klingelnberg, GmbH make lead and profile testing machine.

\section{Discussions}

Higher impact strength of Ni-Cr-Mo alloyed steel was attributed to the alloying of $\mathrm{Ni}$ and Mo. These elements results in the formation of low carbon martensite and thereby imparts sufficient strength and toughness to the steel (Bepari and Shorowordi, 2004). CBS had lower impact strength compared to DBS. In CBS, titanium fixes nitrogen by forming TiN precipitates and free boron in solution segregated to austenite grain boundaries, reduces the cohesive force and thereby impact toughness (Kapadia, et al. 1968; Azarkevich, et al. 1995). However, in DBS titanium presence was in traces, boron reacts with nitrogen and carbon to form precipitates of boron nitride and boron carbide respectively. These precipitates removed from solution at the grain boundaries and thereby improve the impact properties. This is in line with the findings of Irvine and Pickering (1963). Also, Treppschuh et al. (1967) showed that, toughness of case hardened and cold worked steels can be improved by boron addition, provided boron should combine with nitrogen. Tensile strength of DBS steel was $789 \mathrm{MPa}$, much higher compared to CBS steel (383 MPa) and better than existing NiCr-Mo alloyed steel (679 MPa). Boron nitride and boron carbide precipitates at the grain boundaries resulted in precipitation hardening of DBS steel. These precipitates acts as barrier for movement of dislocations and thereby 
Table 3. Mechanical properties and cost comparison of CBS, DBS and Ni-Cr-Mo alloyed steel

\begin{tabular}{|c|c|c|c|c|c|}
\hline Steel & $\begin{array}{c}\text { UTS } \\
\text { (MPa) }\end{array}$ & $\sigma_{\mathbf{0 . 2}}$ (MPa) & $\begin{array}{c}\text { \% Elongation at } \\
\text { ultimate point }\end{array}$ & $\begin{array}{c}\text { \% Elongation at } \\
\text { break point }\end{array}$ & $\begin{array}{c}\text { Cost / Ton in } \\
\text { INR }\end{array}$ \\
\hline CBS & 383 & 334 & 11.73 & 32.6 & 42,000 \\
\hline $\begin{array}{c}\text { Ni-Cr-Mo } \\
\text { steel }\end{array}$ & 679 & 470 & 9.18 & 23.9 & 56,000 \\
\hline DBS & 789 & 454 & 9.20 & 20.6 & 44,000 \\
\hline
\end{tabular}

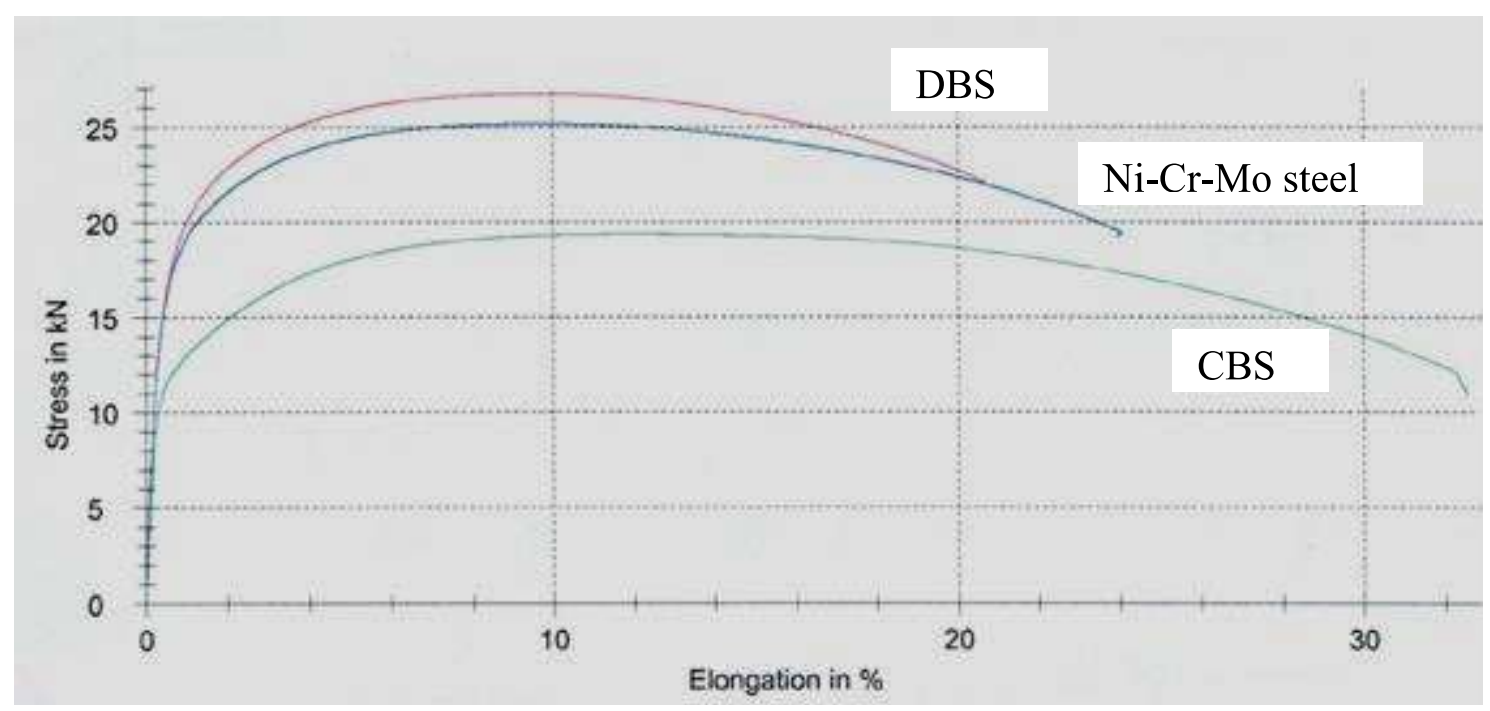

Figure 4. Load deflection curve for Ni-Cr-Mo alloyed steel and boron steels

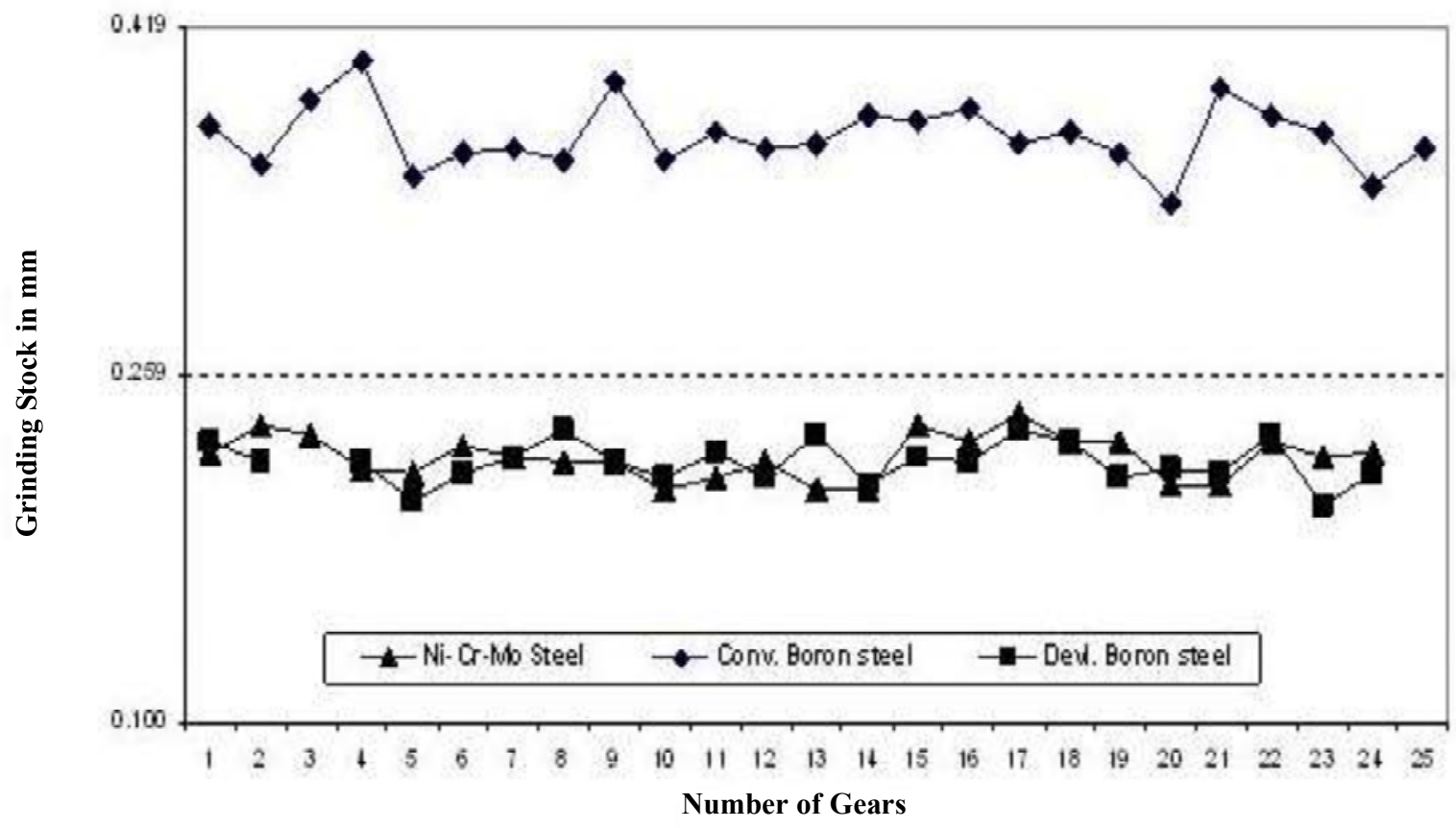

Figure 5. Grinding stock of gears made of Ni-Cr-Mo alloyed and boron steels after CC

imparts higher strength to the DBS. However, in CBS, boron segregation at the grain boundaries resulted in suppression of ferrite and pearlite formation (Brownrigg, 1973). This results in lower strength of CBS steel. Ferrite strengthening effects of $\mathrm{Ni}$ and Mo results in higher strength of the Ni-Cr-Mo alloyed steel (Davis, 2000).
Thermal stresses introduced during case carburization were responsible for dimensional changes or component distortion (Thelning, 1974). These dimensional changes needs to be incorporated in machining tolerance and removed by grinding and finishing. The amount of retained austenite exhibits significant effects on dimen- 
The Journal of Engineering Research Vol. 8 No. 1 (2011) 12-18

Table 4. Metallurgical characterization of gears after $\mathrm{CC}$ and tempering

\begin{tabular}{|c|c|c|c|}
\hline Details & Ni-Cr-Mo steel & $\begin{array}{c}\text { Conven tional } \\
\text { Boron steel }\end{array}$ & $\begin{array}{c}\text { Developed } \\
\text { Boron steel }\end{array}$ \\
\hline Surface hardness & $61 \mathrm{HRc}$ & $60 \mathrm{HRc}$ & $60 \mathrm{HRc}$ \\
\hline $\begin{array}{c}\text { ECD @ Cut off of } \\
600 \mathrm{HV} 1\end{array}$ & $0.85 \mathrm{~mm}$ & $0.80 \mathrm{~mm}$ & $0.80 \mathrm{~mm}$ \\
\hline \multirow{2}{*}{\begin{tabular}{c} 
Core Hardness \\
\cline { 2 - 4 }
\end{tabular}} & At Pcd, 343 HV1 & At Pcd, 339 HV1 & At Pcd, 340 HV1 \\
\hline $\begin{array}{c}\text { Case micro } \\
\text { structure }\end{array}$ & $\begin{array}{c}\text { Tempered martensite with } \\
\text { no carbide network present }\end{array}$ & $\begin{array}{c}\text { Tempered martensite with } \\
\text { no carbide network present }\end{array}$ & $\begin{array}{c}\text { Tempered martensite with } \\
\text { no carbide network present }\end{array}$ \\
\hline $\begin{array}{c}\text { Core micro } \\
\text { structure }\end{array}$ & \multicolumn{3}{|c}{ At Row $325 \mathrm{HV} 1$} \\
\hline
\end{tabular}

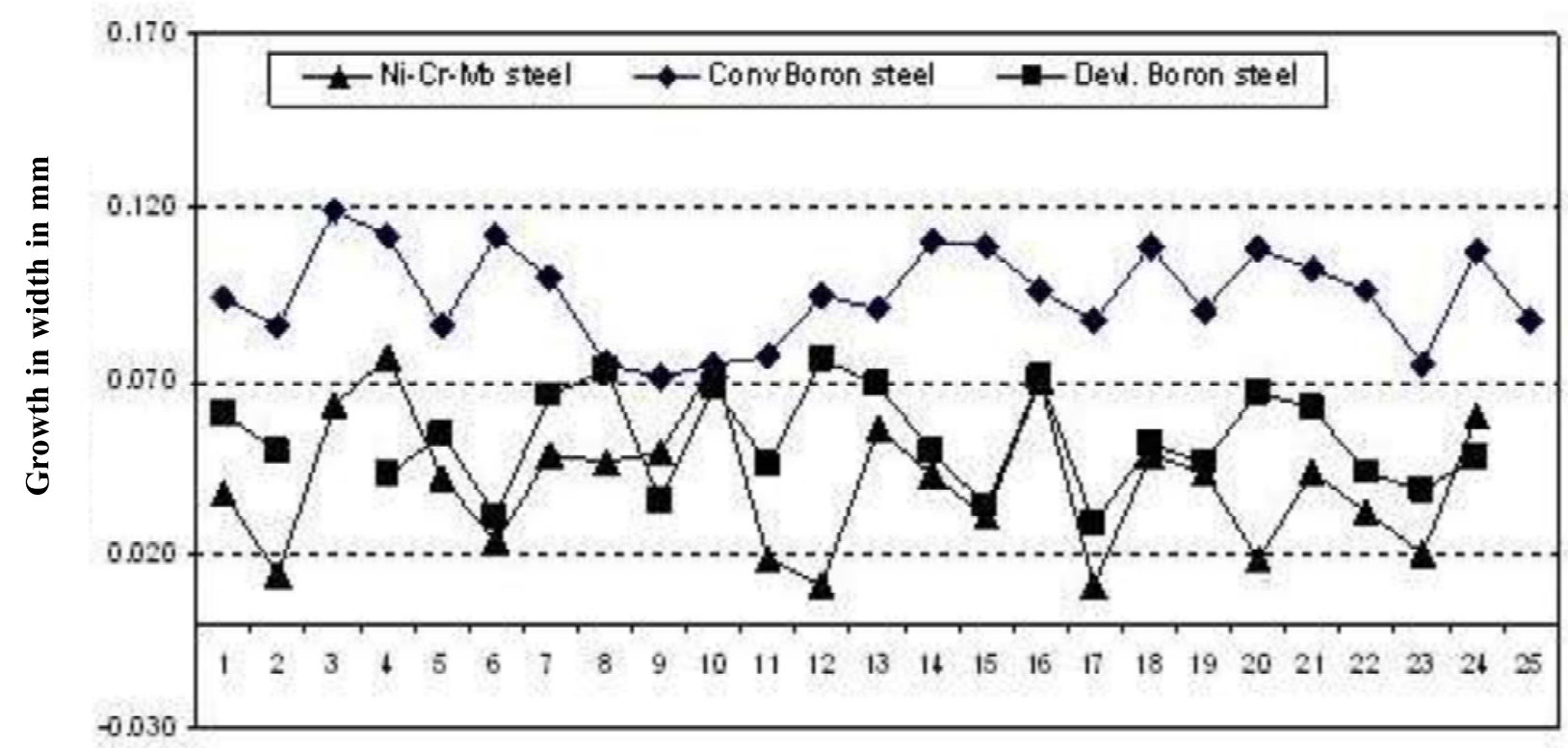

Number of Gears

Figure 6. Width distortion trend of gears made of Ni-Cr-Mo alloyed and boron steels after CC

sional stability. After quenching, steels contain some retained austenite along with martensite which increases with amount of alloying elements dissolved during austenitization. During carburizing, the amount of carbon in the case increases with applied carbon potential, but its increase leads to higher austenite retention (Bensely, 2008). Higher the alloying elements results in higher retained austenite and thereby lower distortion (Stumpf and Banks, 2006; Mohanty, 1995). In addition, presence of Ni suppresses Ms temperature which further enhances retained austenite content. Hence, Ni-Cr-Mo alloyed steel had lower ID and width distortion. Higher retained austenite reduces strength and residual stresses but subsequent tempering reduces retained austenite by transforming to martensite (Parrish, 1999). In CBS, gear ID and width distortion values were higher compared to Ni-Cr-Mo alloyed steel. This was obviously due to lower retained austenite and high carbon martensite in CBS (boron has no effect on Ms temperature). Lower distortion in DBS may be due to controlled and uniform grain size distribution, in contrast to the mixed grain size distribution observed in CBS.

\section{Conclusions}

1. DBS was comparable to the existing $\mathrm{Ni}-\mathrm{Cr}-\mathrm{Mo}$ alloyed gear steel (EN353 of BS 970 standard) and superior to CBS (20MnCr5B). DBS specimens failed at an average impact load of $53.1 \mathrm{kN}$, comparable to $54 \mathrm{kN}$ of Ni-Cr-Mo alloyed steel and higher than $38.68 \mathrm{kN}$ of CBS.

2. Tensile strength of DBS was highest $(789 \mathrm{MPa})$ where as elongation of CBS was highest $(11.73 \%)$. Tensile strength (679 MPa) and elongation $(9.18 \%)$ of $\mathrm{Ni}-\mathrm{Cr}-\mathrm{Mo}$ alloyed steels was in between the two 
boron steels.

3. Distortion of gears ID and width due to carburization of DBS and Ni-Cr-Mo alloyed steel gears were comparable to average of $0.225 \mathrm{~mm}$ and $0.05 \mathrm{~mm}$ respectively. However, distortion of ID and width of CBS gears were higher to $0.400 \mathrm{~mm}$ and $0.09 \mathrm{~mm}$ respectively.

4. Lower distortions of Ni-Cr-Mo alloyed steel were associated with higher retained austenite compared to CBS. However, lower distortion of DBS gears could be due to controlled and uniform grain size distribution.

5. Lower distortion in the DBS against CBS will save finished component cost in terms of tool repair or replacement period, thereby increasing the productivity.

6. With this huge potential of enhanced mechanical properties, lower raw material cost, reduced machining requirements and higher cost savings, DBS can be considered as alternative steel for transmission gears against costly Ni-Cr-Mo alloyed steels and inferior CBS.

\section{Acknowledgment}

The authors are grateful to Mr. K. Parthasarathy, Retd. Dy. General Manager, Product Development, Materials Engineering Department, Ashok Leyland Limited Chennai, India, for their support and technical help. The authors express sincere gratitude to the management of MUSCO steel plant, India for their guidance and co-ordination.

\section{References}

Azarkevich, A.A., Kovalenko, L.V. and Krasnopolskii, V.M., 1995, "The Optimum Content of Boron in Steel," J. of Metal Science and Heat Treatment, Vol. 37(1-2), pp. 22-24.

Bensely, A., Venkatesh, S., Lal, D.M., Nagarajan, G., Rajadurai, A. and Junik, K., 2008, "Effect of Cryogenic Treatment on Distribution of Residual Stress in Case Carburized EN353 Steel," Materials Science and Engineering A, Vol. 479, pp. 229-235.

Bepari, M.M.A. and Shorowordi, K.M, 2004, "Effects of Molybdenum and Nickel Additions on the Structure and Properties of Carburized and Hardened Low Carbon Steels," J. of Materials Processing Technology, Vol. 155-156, pp. 1972-1979.
Brownrigg, A., 1973, "Boron in Steel- A Literature Review 1956-1972," J. of Australian Institute of Metals, Vol. 18(3), pp. 124-136.

Davis, J.R., 2000, ASM Specialty Handbook, ASM International.

Irvine, K.J. and Pickering, F.B., 1957, J. of Iron and Steel Institute, Vol.187, pp. 292-302.

Irvine, K.J. and Pickering, F.B., 1963, J. of Iron and Steel Institute, Vol. 201, pp. 518-526.

Kapadia, B.M., Brown, R.M. and Murphy, W.J., 1968, "The Influence of Nitrogen, Titanium and Zirconium on the Boron Hardenability Effect in Constructional Alloy Steels," Trans. of the Metallurgical Society of AIME, Vol. 242, pp. 1689-1694.

Melloy, G.F., Slimmon, P.R. and Podgursky, P.P., 1973, "Optimizing the Boron Effect," J. of Metallurgical and Materials Transaction B, Vol. 4(10), pp. 22792289.

Mohanty, O.N., 1995, "On the Stabilization of Retained Austenite: Mechanism and Kinetics," Materials Science and Engineering B, Vol. 32, pp. 267-278.

Parrish, G., 1999, "Carburizing: Microstructure and Properties," ASM International.

Rahrer, G.D. and Armstrong, C.D., 1947, "The Effect of Carbon Content on the Hardenability of Boron Steels," Trans. of the ASM, Vol. 40, pp. 1099-1112.

Stumpf, W. and Banks, K., 2006, "The Hot Working Characteristics of a Boron Bearing and a Conventional Low Carbon Steel," Materials Science and Engineering A, Vol. 418, pp. 86-94.

Szuch, R.L. and Delve, F.D., 1967, "Hardenability of Boron Treated Carbon Steels," J. of Blast Furnace and Steel Plant, pp. 930-936.

Thelning, K.E., 1974, "Steel and its Heat Treatment," Bofors Handbook, Butterworths, London, pp. 466 471.

Tikhonov, A.K. and Palagin, Y.M., 1994, "Method of Testing Gear Wheels in Impact Bending, Technical Information," Metal Science and Heat Treatment, Vol. 36(12), pp. $655-657$.

Treppschuh, H., Randak, A., Domalski, H.H. and Kurzeja, J., 1967, "Influence of Boron in the Properties of Structure Steels and Tool Steel," Vol. 87, pp. 1355-1366.

Wilks, T.P., Cavallaro, G.P., Subramanian, C., Strafford, K.N., French, P. and Allison, J. E., 1994, "Conditions Prevailing in the Carburizing Process and their Effect on the Fatigue Properties of Carburized Gears," J. of Materials Processing Technology, Vol. 40, pp. 111125. 